\title{
COARCTATION OF THE AORTA
}

\author{
REVIEW OF TWENTY-THREE SERVICE CASES
}

\author{
BY \\ MAURICE NEWMAN
}

Received May 8, 1948

In Maude Abbott's series of 200 autopsied cases of coarctation of the aorta published in 1928, there were only 21 cases in which the diagnosis had been made during life. Since Lewis' paper (1933), and especially since the radiological features of coarctation were described by Roesler (1928) and by Railsback and Dock (1929), the clinical diagnosis has been made far more frequently.

The purpose of this paper is to present a brief analysis of 20 cases of coarctation of the aorta who served in the recent war, that have been collected in going through the records of the Ministry of Pensions service documents. These cases have not been examined personally, but their records contain full details of pre-war occupation, examination prior to enlistment, duration and nature of service, clinical and radiological signs of coarctation found, and sometimes the after history. To these 20 cases have been added 3 who served in the 1914-18 war where the diagnosis of coarctation was made in later years. One of these has been described by Lewis (Case 2) but it has been included here because the service documents provide additional information of interest.

\section{Service History}

Age. Table I shows the age when coarctation of the aorta was first diagnosed in the recent war cases. The youngest was 19 and the oldest 37: five were over 30 years of age. All were males.

Body Build. Table I also shows the height and weight on entry into Service, at a younger age than that recorded in column 2, when the coarctation was diagnosed. The striking feature was the good physical development and nourishment in the majority. In about half of the series the recorded weight on entry into the services was over $140 \mathrm{lb}$. Remarks such as " sturdy build," " heavily built," " powerful physique" were recorded in many cases, and all but 3 were graded fit for general service, or Grade I on entry. In the three exceptions, the lowered category was due to the condition of the feet in one (Case 11), to the eyes in another (Case 18), and only once to the heart, in Case 6, diagnosed as mitral regurgitation on grounds of a systolic murmur heard in the mitral and aortic areas; the body weight in this case was $167 \mathrm{lb}$.

It is interesting to note at this stage that in four other cases $(10,11,12$, and 19) a systolic murmur was noted at examination on entry, which was not regarded of such significance as to justify lowering the category. Case 12 was graded I after a cardiologist's report diagnosing a slight congenital defect. In five out of the twenty cases, therefore, a cardiac murmur was known to be present prior to the diagnosis of coarctation.

Pre-Service Occupation. It will be seen (Table I) that in only two of the series was the occupation sedentary. Of the non-sedentary occupations about half may be considered as involving heavy work. Case 5 was an athlete who played rugby football and was a quarter mile runner. Case 7 played all games well at school and played football when he joined the Navy. Case 19 was a county hockey player.

Pre-Service history of Rheumatism. On examination prior to entry into Service all are questioned, and the answer recorded, as to whether he or she has suffered from rheumatic fever or rheumatism in the past. In the series of 20 recent war cases there was a history of rheumatic fever, rheumatism or chorea in 4. Case 2 recorded chorea at the age of 12, with 4 months absence from school; Case 4 muscular rheumatism in adolescence; Case 5 rheumatic fever when aged 7 and a recurrence at age 10, and Case 18 rheumatic fever when aged 18 . This series, however, is too small to come to any conclusion as to whether cases of coarctation of the aorta are more vulnerable than normal to rheumatic infection. In Abbott's series of 70 cases, only 8 had a history of rheumatism.

Service prior to Cardiac Breakdown. The majority 
TABLE I

Twenty Cases Serving in Recent War

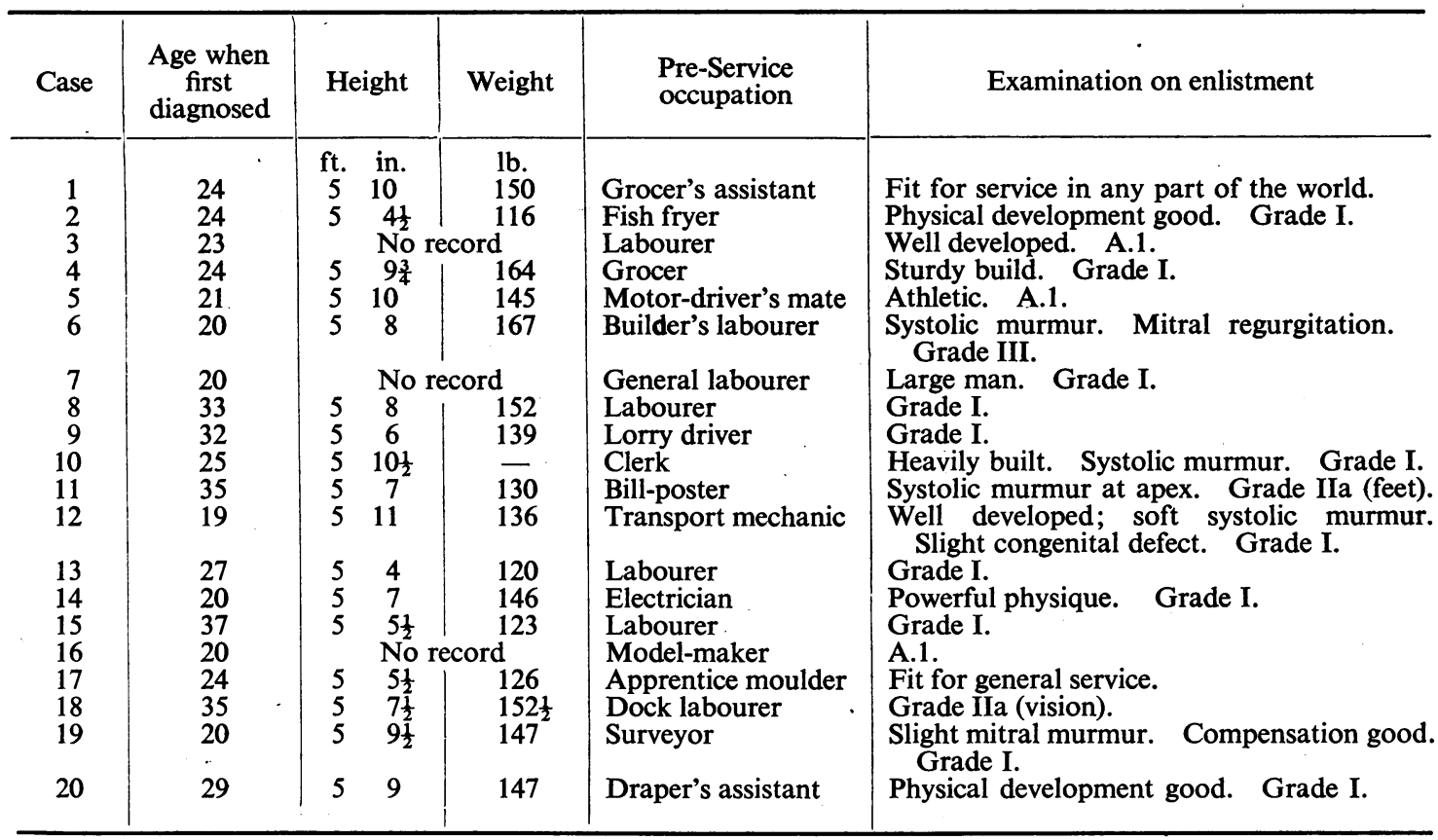

served for several years as Grade I men, doing intensive training, and subjected to all the stress and strain of war, including overseas service. Two (Cases 11 and 15) were only discovered on routine examination for service overseas after two years' in the forces. This clearly demonstrates that men with coarctation may have the capacity to withstand severe physical strain for prolonged periods without any symptoms or signs of heart failure appearing.

\section{Clinical Findings}

Table II gives an analysis of the clinical findings in 22 cases including 3 of the 1914-18 war (Cases 21, 22, and 23). Case 20, only diagnosed at autopsy, is not included.

Arterial Blood Pressure. A raised blood pressure in the upper limbs is one of the most constant signs in coarctation of the aorta. From Table II it will be seen that this was raised in every case in this series. The lowest pressure recorded was $144 / 90 \mathrm{~mm}$. (Case 19), but this man was only 20 years of age when the coarctation was diagnosed. He was aware that he had a "leaking heart" as a lesion had been discovered on routine examination at school, when aged 15. As there were no symptoms, no restriction on activity was imposed; he played strenuous games and was a county hockey player. When examined a slight mitral murmur was detected but compensation was stated to be good and he was passed fit for general duties. After two years' service, coarctation of the aorta was diagnosed but in the absence of symptoms he was retained in Category C. He remained well for another three years until subacute bacterial endocarditis supervened and rapidly proved fatal.

Where the blood pressure is recorded separately in each arm it will be noted that there is sometimes a difference between the two readings. Usually it is lower in the left arm owing to the diminished circulation that results from the coarctation encroaching upon the orifice of the left subclavian artery. In four cases, where the blood pressure in both arms was recorded, it was lower in the left arm than in the right, and once (Case 6) it was lower in the right.

Blood Pressure in the Legs. In every case there was a marked lowering of the arterial pressure in the lower limbs compared with the upper, and in many there was absence of the femoral pulse. This emphasizes the importance of always palpating the femoral pulse in hypertension, especially in young people. As the result of deficient circulation to the lower limbs symptoms of intermittent claudication may occur, as happened in Case 7 four years after coarctation had been diagnosed. 
TABLE II

Analysis of Clinical Findings in 22 Cases

\begin{tabular}{|c|c|c|c|c|c|c|}
\hline \multirow{2}{*}{ Case } & \multicolumn{2}{|c|}{ Blood pressure } & \multirow{2}{*}{ Murmurs } & \multirow{2}{*}{$\begin{array}{l}\text { Pulsation } \\
\text { root of neck }\end{array}$} & \multirow{2}{*}{$\begin{array}{l}\text { Collateral } \\
\text { circulation }\end{array}$} & \multirow{2}{*}{$\begin{array}{c}\text { Cardiac } \\
\text { enlargement }\end{array}$} \\
\hline & Brachial & Femoral & & & & \\
\hline-1 & $\begin{array}{l}\text { RA. } 185 / 110 \\
\text { LA. } 150 / 90\end{array}$ & $102 / ?$ & $\begin{array}{l}\text { Loud, blowing systolic axilla and } \\
\text { back }\end{array}$ & + & - & + \\
\hline 2 & $200 / 140$ & - & $\begin{array}{l}\text { Soft systolic and blowing diastolic; } \\
\text { loud systolic medial to scapula }\end{array}$ & + & + & - \\
\hline 3 & $156 / 92$ & $104 / 80$ & $\begin{array}{l}\text { Harsh loud systolic all areas and } \\
\text { back }\end{array}$ & + & + & Slight \\
\hline 4 & $225 / 120$ & - & $\begin{array}{l}\text { Systolic-also over inte nal mam- } \\
\text { mary and supra scapula arteries }\end{array}$ & + & + & + \\
\hline 5 & $\begin{array}{l}\text { RA. } 250 / 160 \\
\text { LA. } 210 / 120\end{array}$ & 一 & Loud systolic præcordium and back & + & + & Slight \\
\hline 6 & $\begin{array}{l}\text { RA. } 195 / 110 \\
\text { LA. } 225 / 115\end{array}$ & - & Systolic apex and aortic area & - & - & + \\
\hline 7 & $\begin{array}{l}\text { RA. } 204 / 120 \\
\text { LA. } 188 / 110\end{array}$ & - & Systolic præcordium & + & + & + \\
\hline$\cdot \begin{array}{l}8 \\
9\end{array}$ & $\begin{array}{l}210 / 100 \\
225 / 115\end{array}$ & $17 \overline{5 / 120}$ & $\begin{array}{l}\text { Soft systolic apex: diastolic base } \\
\text { Systolic all areas }\end{array}$ & $\bar{t}$ & $\bar{t}$ & $\stackrel{+}{+}$ \\
\hline 10 & $190 / 100$ & 10 & Loud apical systolic & + & + & + \\
\hline 11 & $200 / 110$ & $140 / 120$ & Loud systolic præcordium & + & + & + \\
\hline 12 & $\begin{array}{l}200 / 110 \\
R \text { and } L\end{array}$ & $110 / ?$ & $\begin{array}{l}\text { Soft systolic over præcordium and } \\
\text { paravertebral region near scapula }\end{array}$ & - & - & + \\
\hline $\begin{array}{l}13 \\
14\end{array}$ & $\begin{array}{l}200 / 105 \\
210 / 110\end{array}$ & 二 & $\begin{array}{l}\text { Loud systolic over præcordium } \\
\text { Rough basal systolic }\end{array}$ & - & $\overline{-}$ & 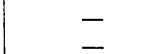 \\
\hline 15 & $\begin{array}{l}230 / 120 \\
\mathrm{R} \text { and } \mathrm{L}\end{array}$ & $130 / ?$ & $\begin{array}{l}\text { Rough basal systolic maximal pul- } \\
\text { monary area }\end{array}$ & $\bar{t}$ & $\bar{t}$ & - \\
\hline 16 & $\begin{array}{l}168 / 100 \\
R \text { and } L\end{array}$ & ? & $\begin{array}{l}\text { Blowing systolic over pulmonary } \\
\text { area }\end{array}$ & - & - & - \\
\hline 17 & $\begin{array}{l}\text { RA.195/105 } \\
\text { LA.185/95 }\end{array}$ & $80 / 2$ & $\begin{array}{l}\text { Harsh aortic systolic and blowing } \\
\text { diastolic }\end{array}$ & + & + & + \\
\hline 18 & $180 / 110$ & - & $\begin{array}{l}\text { Loud systolic all areas best heard } \\
\text { over 3rd left space }\end{array}$ & - & - & + \\
\hline 19 & $144 / 90$ & - & $\begin{array}{l}\text { Loud systolic all areas. Loud } \\
\text { diastolic } 2 \text { nd and } 3 \text { rd right space }\end{array}$ & + & + & + \\
\hline $\begin{array}{l}21 \\
22\end{array}$ & $\begin{array}{l}190 / 110 \\
178 / 102\end{array}$ & $130 / ?$ & $\begin{array}{l}\text { Systolic apex and } 2 \text { nd right space } \\
\text { Loud blowing systolic at apex con- } \\
\text { ducted widely }\end{array}$ & + & + & + \\
\hline 23 & $276 / 120$ & $156 / 120$ & $\begin{array}{l}\text { Systolic over all areas including } \\
\text { back }\end{array}$ & + & + & + \\
\hline
\end{tabular}

Murmurs. The characteristic murmurs of coarctation of the aorta are systolic in time, sometimes loud and harsh in intensity, and heard all over the præcordium, often at the back in the region of the scapula, and over the dilated arteries forming the collateral circulation. Systolic murmurs were recorded in every case in this series. In 7 the murmur was heard posteriorly. Reifenstein et al. (1947) in reviewing 104 autopsied cases state that systolic murmurs were heard in all 60 in which mention was made of physical examination of the heart, and in $\mathbf{2 3}$ of them the murmur was heard posteriorly. A systolic murmur is, therefore, to be regarded as one of the most constant findings in coarctation.

In four (Cases 2, 8, 17, and 19) a diastolic murmur was also present. Reifenstein et al. state that a diastolic murmur is not found in uncomplicated coarctation of the aorta, but only when there is an associated aortic valvular deformity, including bacterial endocarditis or patency of the ductus arteriosus. In Case 2 of my series, the diastolic murmur was most likely due to acquired rheumatic aortic incompetence, dating from an attack of chorea when he was 12 , which necessitated four months absence from school. In Case 8 the diastolic murmur was also likely due to an associated aortic regurgitation, for there was a history of rheumatism, and though the Wassermann reaction during Service was strongly positive, it was not considered to have any connection with the cardiac lesion. In Case 17 radiological examination showed calcification of the aortic arch and probably an aneurysmal dilatation, which would explain the diastolic murmur. Case 19 is the one already described which developed bacterial endocarditis, and an aortic valvular defect was probable. Con- 
genital bicuspid aortic valve is a common associated lesion in coarctation of the aorta, occurring in 24 per cent of Abbott's series (1928).

Pulsation at the root of the Neck. Bramwell has pointed out that excessive arterial pulsation at the root of the neck should be included as one of the classical signs of coarctation of the aorta. In my series this sign was noted in 15 and not noted in 7 of the 22 cases. Once (Case 21) the association of marked visible pulsation in the suprasternal notch with a murmur in the aortic area, transmitted to the neck, led to an initial diagnosis of aortic aneurysm.

Collateral Circulation. Dilated collateral vessels were not observed in 9 of the 22 cases in this series, and therefore are not to be regarded as a sign that is essential for diagnosis of coarctation. Campbell and Suzman (1947) have recently described a special method of demonstrating the collateral vessels when they are not normally evident.

Radiological Diagnosis. Although coarctation of the aorta may be diagnosed on clinical signs alone, many more cases have been diagnosed during life since erosion or notching of the lower borders of the ribs was described by Roesler (1928) and by Railsback and Dock (1929). Notching of the ribs depends on the development of the collateral circulation inside the thorax, and is not present in every case. If there is a patent ductus arteriosus, rib notching is usually absent (Bramwell, 1947).

In the 22 cases of my series, rib erosion was recorded in 16 , and was probably present in a further case (Case 6) in which coarctation of the aorta was diagnosed radiologically, though details were not given. In Case 1, although no rib erosion was detected, there was some erosion seen at either end of the left clavicle. This leaves only 4 out of 22 cases in which no erosion occurred (Cases 4, 9, $10,21)$, and in these collateral vessels were present. In Bramwell's series of 26 cases rib notching was absent in 4 cases. On the other hand, 6 cases showed notching of the ribs without clinical evidence of a collateral circulation (Cases 8, 12, 13, 14, 16, and 18). It must be concluded, therefore, that rib notching is a valuable diagnostic sign of coarctation of the aorta.

Absence or smallness of the aortic knuckle also. appears to be a valuable sign of coarctation of the aorta, for in only two cases (Cases 10 and 14) was the aortic knuckle not reduced in size. In Perlman's series of 13 cases, the aortic knuckle was absent in every case, and all of them showed some rib erosion.

Radiological enlargement of the heart, usually the left ventricle, was noted in 16 of 21 cases of this series. (In Case 6, details of radiological findings were not recorded.) Enlargement of the heart did not appear to have any relation to the blood pressure. In 4 of the 5 cases with no enlargement the systolic blood pressure in the arms was $200 \mathrm{~mm}$. or over (Cases 2, 13, 14, and 15). Unlike essential hypertension, the high blood pressure in coarctation of the aorta does not necessarily cause cardiac enlargement, as Lewis has emphasized.

In five (Cases 1, 4, 5, 6, and 16), the diagnosis was made by the radiologist. Case 1 was at first diagnosed as mitral stenosis. In Case 4 no cardiac disability was suspected prior to a routine X-ray examination of the chest whilst convalescing from diphtheria. Case 5 was X-rayed following a collapse whilst playing rugby football. Case 6 was at first thought to be one of polycythæmia vera with hypertension. In Case 16 the chest was X-rayed on account of bronchitis and asthma.

In Case 10 there was no radiological evidence of coarctation of the aorta. This man was a clerk before he joined the Royal Air Force in July 1940. At his medical examination prior to enlistment a systolic murmur was noted but was not regarded as of any significance and he was graded I. There was no history of rheumatic fever or chorea but he was unable to play games during his last four terms at school owing to shortness of breath. In March, 1941, he was examined for fitness for a commission as a pilot and was rejected. A systolic murmur was noted at the apex and his blood pressure was $188 / 92 \mathrm{~mm}$. The diagnosis of hyperpiesia with cardiac bruit was made. He was re-examined in October, 1941, owing to complaints of dyspnoea and attacks of pain over the heart, and his blood pressure was then $200 / 100 \mathrm{~mm}$.; he was still Grade $I$. He was referred to a specialist who diagnosed mitral disease with hypertension. He continued to serve until October, 1944, when he collapsed and was found unconscious at a railway station whilst being posted. He was transferred to Middlesex Hospital where, after complete investigations, coarctation of the aorta was diagnosed, although there was no radiological evidence of it. No erosion of the ribs was present and the aortic knuckle was prominent and high. Tomograph of the aorta revealed no narrowing. The barium swallow showed no enlargement of the left auricle but the left ventricle was slightly enlarged. However, all the characteristic clinical signs of coarctation were present, namely increased blood pressure in the upper limbs $(190 / 100 \mathrm{~mm}$.), absence of femoral pulsation, marked arterial pulsation in the neck and below the outer third of the clavicle, a loud systolic murmur at the apex of the heart and a collateral circulation in the axilla and scapular regions.

Electrocardiographic examinations were recorded 
in several cases but were not of diagnostic help. In Case 19 a conduction defect was shown.

Prognosis. Bramwell concluded that patients with coarctation of the aorta whose symptoms date from childhood are unlikely to reach the age of 30 , whereas in those who are free from symptoms until 30 , the outlook is much more favourable.

All of the recent war cases under discussion have reached adult life; the youngest case was aged 19 and the oldest aged 37; fifteen were under 30 years of age. As already stated, the majority were of good physical development and fit enough to be graded I. It would appear, therefore, that if symptoms do not become manifest in childhood there is no retardation of physical development or diminished fitness, and that such subjects are able to perform heavy physical work for a prolonged period without any symptoms or signs of cardiac failure, though eventually prolonged stress may cause cardiac symptoms.

Table III shows the history of the 20 recent war cases after discharge. Three deaths are recorded. Case 20 died suddenly, at the age of 29 , from rupture of the aorta whilst on leave after five years' army service as a Grade I man. Neither prior to, nor during his five years' service, had there been any symptoms or signs of heart trouble. He was examined on entry, and had twice been passed fit for overseas service without the detection of any cardiac disability. The autopsy findings were as follows :-

"Very well-developed, well-nourished man.

TABLE III

History of Recent War Cases after Discharge

\begin{tabular}{|c|c|c|c|}
\hline Case & $\begin{array}{l}\text { Date of } \\
\text { diagnosis }\end{array}$ & $\begin{array}{l}\text { Date of } \\
\text { discharge }\end{array}$ & \\
\hline 1 & 5.1 .40 & 16.4 .40 & $\begin{array}{l}\text { Worked as N.A.A.F.I. manager. Developed pulmonary tuberculosis } 21.10 .45 \text {. } \\
\text { October, 1947, well and working. }\end{array}$ \\
\hline 2 & $\begin{array}{l}\text { November, } \\
1945\end{array}$ & 24.3.46 & Working as a fitter, only symptom slight shortness of breath on exertion. \\
\hline 3 & 11.8 .43 & 23.3.44 & $\begin{array}{l}\text { Clerical work. Complained of fainting attacks. Admitted to Royal Infirmary, } \\
\text { Edinburgh, } 18.12 .46 \text { for operation. Died from cardiac failure at close of } \\
\text { operation. }\end{array}$ \\
\hline $\begin{array}{l}4 \\
5\end{array}$ & $\begin{array}{l}3.8 .43 \\
\text { December, } \\
1940\end{array}$ & $\begin{array}{l}11.12 .43 \\
10.1 .41\end{array}$ & $\begin{array}{l}\text { Resumed pre-service occupation: has occasional days off. } \\
\text { 17.9.46. Worked as light vehicle driver and later as fitter. Short of breath, } \\
\text { headache, occasional dizziness. }\end{array}$ \\
\hline $\begin{array}{l}6 \\
7\end{array}$ & $\begin{array}{l}17.2 .41 \\
15.2 .42\end{array}$ & $\begin{array}{l}2.4 .41 \\
31.3 .42\end{array}$ & $\begin{array}{l}\text { No further history: no claim for pension. } \\
\text { 15.10.46. Working general handyman in building trade. Shortness of breath }\end{array}$ \\
\hline 8 & 26.6.44 & 11.6 .40 & $\begin{array}{l}\text { Invalided from service, diagnosis myocardial degeneration. Coarctation } \\
\text { diagnosed by medical board } 26.6 .44 \text {. On } 13.12 .46 \text { working in grocery } \\
\text { business. B.P. 200/120. No congestive failure. }\end{array}$ \\
\hline $\begin{array}{r}9 \\
10\end{array}$ & $\begin{array}{l}22.3 .45 \\
3.10 .44\end{array}$ & $\begin{array}{l}4.10 .45 \\
21.4 .45\end{array}$ & $\begin{array}{l}\text { No further history. } \\
\text { Working in radio trade. }\end{array}$ \\
\hline 11 & 14.2 & & $\begin{array}{l}\text { 4.2.47. Complains of headaches, easily tired, short of breath on exertion. } \\
\text { Works at pre-war occupation-bill poster. }\end{array}$ \\
\hline 12 & 6.4 .45 & 19.8.45 & $\begin{array}{l}\text { 21.1.47. Shortness of breath, occasional pain in the chest, dizziness. Worked } \\
\text { for three months after discharge then gave it up. }\end{array}$ \\
\hline 13 & $\begin{array}{l}\text { November, } \\
1945\end{array}$ & 19.11.45 & $\begin{array}{l}\text { 5.12.46. Pain across upper part of chest at night lasting half hour. Works as } \\
\text { refuse collector for council: no loss of time. B.P. 190/120. No evidence } \\
\text { of enlargement of left ventricle. }\end{array}$ \\
\hline 14 & 23.6.41 & 28.3.44 & $\begin{array}{l}\text { 24.1.47. Shortness of breath on exertion, feels tired. General condition } \\
\text { good. B.P. } 225 / 110 \text {. }\end{array}$ \\
\hline 15 & 11.5.44 & 7.6.45 & $\begin{array}{l}\text { July, 1947. Pains over præcordium. Works as lorry driver. Heart not } \\
\text { enlarged. Visible pulsation in neck. }\end{array}$ \\
\hline 16 & 22.12.4 & 1 & $\begin{array}{l}\text { 7.10.46. Short of breath on exertion. Joiner, March, } 1945 \text { to May, 1946, } \\
\text { then lighter work as telephone wireman. General condition good. }\end{array}$ \\
\hline 17 & 27.8.45 & 9.1 .46 & $\begin{array}{l}\text { 11.3.47. Shortness of breath and dizzy attacks. Clerk, loses one day a week. } \\
\text { B.P. } 235 / 115 \text {. Heart enlarged, marked visible pulsation in neck. }\end{array}$ \\
\hline 18 & 30.5.45 & 13.3.41 & $\begin{array}{l}\text { Invalided as rheumatic endocarditis. Coarctation diagnosed by medical board, } \\
\text { 30.5.45. Working as cinema doorman. Electrocardiogram shows myo- } \\
\text { cardial damage. }\end{array}$ \\
\hline 19 & 14.8.41 & 11.4.44 & $\begin{array}{l}\text { 7.5.44. Developed symptoms and signs of subacute bacterial endocarditis } \\
\text { from which he died. }\end{array}$ \\
\hline 20 & 27.8.45 & - & $\begin{array}{l}\text { Died suddenly whilst on leave. Autopsy showed coarctation with rupture of } \\
\text { the aorta. }\end{array}$ \\
\hline
\end{tabular}


Pericardial sac distended with blood clot, ragged aperture at the back of the aorta. Heart very large, $700 \mathrm{~g}$. Left ventricle much hypertrophied, muscle firm. Moderate degree of coarctation of the aorta and patchy atheroma above the aortic valves. A ragged triangular tear in the intima just above the right coronary artery. This opens into a dissecting aneurysm which has stripped off the intima over the greater part of the ascending aorta and arch. Considerable amiount of blood in the coats of the vessel, and rupture has occurred into the pericardium through the back of the ascending aorta. There is nothing in any way suggestive of specific disease. Extensive atheroma of the vessels at the base of the brain.

"Conclusions. Coarctation of the aorta with hypertrophy of the left ventricle and a dissecting aneurysm of the first part of the aorta which has ruptured into the pericardium."

According to Blackford (1928) sudden death from rupture of the aorta during or following severe exertion is not uncommon in coarctation of the aorta. Case 3 died on the operating table from cardiac failure during operation for the coarctation. At the operation coarctation was found immediately distal to the left subclavian artery, and the intercostal vessels were much dilated. The other patient who died, Case 19, developed subacute bacterial endocarditis, after having served for 6 years. He was diagnosed as coarctation in August, 1941, but as he had no symptoms he was retained in service in a low category. Three years later subacute infective endocarditis supervened.

All the other recent war cases, as far as is known, are still living. Case 1 developed pulmonary tuberculosis with positive sputum in October, 1945, - five and a half years after discharge-but when examined for review of pension in October, 1947, was working and feeling well. Case 7, when examined in October, 1946, had developed typical symptoms of intermittent claudication, but was working as a general handyman in the building trade. Most of the remaining cases are able to carry on light work, although complaining of symptoms such as shortness of breath on exertion, pains in the chest, and giddiness.

The 1914-18 war cases which have now been followed for a long period of years will be described more fully.

Case 21 (Case 2 in Lewis' series) was examined for enlistment in the Royal Field Artillery in January, 1915. His occupation was described as a carman and washer in a garage and he gave his age as 35 , though later documents show that his actual age on enlistment was 38 years. Physical development is recorded as good and he was passed fit for general service. He served for three and a half years including three months in France and two and a half years in Salonica. In 1916 and 1917 he was admitted to hospital on several occasions for malaria, but there is no record of any other complaints. On Nov. 26, 1917, whilst convalescing at Corfu from an attack of malaria, he was admitted to the British Military Hospital complaining of shortness of breath on exertion and slight pain in the region of the heart. The bood pressure on admission was $240 \mathrm{~mm}$. Examination of the heart showed a systolic murmur at the apex transmitted to the axilla and a systolic murmur in the aortic area transmitted into the neck. The pulse was collapsing. "D.A.H." was diagnosed. On invaliding home he was transferred to hospital and in February, 1918, examination showed a soft systolic musical murmur over the tricuspid area, and a . second systolic murmur in the aortic area. There was also a " soft murmur above the notch, also audible over both sides of the back from apices to level of fourth dorsal vertebra, 4 in. beyond middle line on left side and 3 in. on right side." Visible pulsation in the suprasternal notch was noted and a distinct diastolic shock over left upper front. On X-ray examination no pulsation was seen but shadow of the large vessels seemed enlarged. The Wassermann reaction was positive on Feb. 20, 1918, but negative on April 10, 1918. On June 21, 1918, he was invalided from the Service with the diagnosis of aortic aneurysm.

It is clear from the above clinical notes that many of the characteristic signs of coarctation of the aorta were present at this early date, $1917-18$, as shown by the high blood pressure of $240 \mathrm{~mm}$., the systolic murmur over the præcordium, also heard at the back, and visible pulsation in the neck above the sternum.

When examined by a Medical Board including a cardiologist in November, 1919, it was stated there were no signs of aneurysm. The blood pressure recorded was $250 \mathrm{~mm}$. The man was next medically boarded in 1922 when the blood pressure was still $250 \mathrm{~mm}$., and the heart was recorded as enlarged. The urine showed albumin and casts and the diagnosis was changed to nephritis with enlarged heart. In November, 1925, he was admitted to hospital under Sir Thomas Lewis who diagnosed coarctation of the aorta on the grounds of a collateral circulation and weakening of the femoral pulse. In September, 1939, he had an operation for removal of a renal calculus with no untoward effects. On March 2, 1940, he collapsed whilst trying to sweep the snow from the front of his house. He complained of severe pain in the left arm and back, and shortness of breath. Examination showed marked pulsation above and below both clavicles, an irregular heart due to extrasystoles and the blood pressure in the arm was $190 / 110 \mathrm{~mm}$. and in the legs $130 \mathrm{~mm}$. systolic.

In November, 1942, he was admitted to hospital with pain in the chest and hæmoptysis. He had had eight attacks of loss of consciousness during the preceding two weeks, and heart block was found. He improved with treatment and when seen by a Ministry of Pensions Medical Officer in January, 1944, he was keeping fairly 
well. He died, however, in October of the same year, at the age of 68 .

Case 22 was a greengrocer. He enlisted in June, 1915 , at the age of 20 , and was found fit. He served for a year and was then discharged with V.D.H. (mitral obstruction). The clinical notes recorded a presystolic thrill and murmur at the apex, increase of cardiac dullness and tumultous action of the heart. Examination a year later recorded a slight systolic murmur not conducted. On lying down various murmurs were heard. He had given up work as a stores-porter, as he found it too heavy. In 1922 a medical board reported symptoms of pain over the left side of the chest and back. The heart was enlarged clinically, the heart sounds irregular with a presystolic murmur at the apex. The diagnosis was mitral stenosis with fibrillation. When examined in 1924, complaints were giddiness, shortness of breath, and præcordial pain. The heart was moderately enlarged, rhythm normal (quinidine had been given) and there was a short diastolic murmur at the apex. In 1929 it was recorded that the man had done no work for the last year. There was some cyanosis, the heart was enlarged with systolic and diastolic murmurs at the apex, and the rhythm irregular.

In April, 1932, the man was admitted to Roehampton Hospital where coarctation of the aorta was diagnosed by the radiologist. The clinical notes recorded the apex beat an inch outside the nipple line, and à loud blowing apical systolic murmur conducted widely. No collateral circulation was detected. Marked pulsation in the vessels of the neck was present. Blood pressure in arms 178/102 mm.; femoral pulse not felt. The radiological report was " Heart considerably enlarged in all diameters; aortic arch small. Bilateral irregularity of lower margins of ribs. Appearance of coarctation of the aorta."

When seen in December, 1940, he was confined to bed with influenza. He stated he had been keeping fairly well since he had been in hospital and had been working as a shop-porter. Examination showed evidence of heart block. The pulse was regular rate. 42. The blood pressure in the arms was $195 / 100 \mathrm{~mm}$. He was last seen in September, 1941, when he was confined to bed, dyspnœic and cyanosed. Pulse rate 42. Blood pressure $180 / 100 \mathrm{~mm}$. There was evidence of congestive failure, namely, râles at the lung bases and some œedema of the legs. This was twenty-five years after the onset of symptoms.

Case 23. This man enlisted in October, 1916, at the age of 24 and went to France. In May, 1918, he was admitted to hospital with the diagnosis of pyrexia of unknown origin. He complained of pains, shivering and vertigo. Examination revealed a loud systolic murmur over the præcordium, best heard at the apex and conducted to the axilla, and also heard at the back at the level of the second to fifth dorsal vertebræ. There was marked pulsations at the root of the neck. Radiological examination showed enlarged root shadows, no aneurysm, and a very greatly enlarged heart. The man was invalided with the diagnosis of V.D.H. In 1922 the man was complaining of shortness of breath, pain over the heart, and faintness at times. A systolic bruit was noted at the apex and base of the heart, but no presystolic or diastolic murmur. In 1925 his symptoms were worse. The blood pressure, recorded for the first time, was $200 / 90 \mathrm{~mm}$. A harsh systolic murmur was noted at the apex and base.

In 1931 the man was admitted to Roehampton Hospital. It was stated he had been doing his usual work as a labourer. He complained of giddiness and faintness. The apex beat was forcible and outside the nipple line. A systolic murmur was present over the aortic and mitral areas; no diastolic murmur was present. There was forcible pulsation at the root of the neck. Blood pressure was $255 / 120 \mathrm{~mm}$., the radiologist's report was as follows:-

"Enlargement of the left side of the heart, usual projection of the aortic arch not shown, irregularity of the lower rib margins on both sides from the third

rib downwards. Appearance that of coarctation of the aorta."

In 1935 he was only able to do light work owing to pain across the chest and fainting attacks. The blood pressure in the arm was $230 / 110 \mathrm{~mm}$. The femoral pulse could not be felt. The Wassermann reaction was negative. The cardiogram showed left ventricular preponderance and slight widening of the QRS complexes.

In 1937 he was working as a casual labourer. There was visible pulsation under the left clavicle. No collateral vessels were detected. The brachial blood pressure was $260 / 145 \mathrm{~mm}$. The right femoral pulse was just palpable but there was no pulsation in the left.

When last seen, in December, 1946, aged 54, he could not walk far. There was triple rhythm at the apex but no congestive failure.

These records show that patients with coarctation of the aorta may live for many years after the first appearance of signs and symptoms, and in spite of persistent hypertension. For example, Case 21 survived for 27 years after signs of coarctation and a blood pressure of $240 \mathrm{~mm}$. were first recorded, and Case 23 was alive and free from congestive failure 21 years after his blood pressure had been recorded as $200 / 90 \mathrm{~mm}$.

\section{SumMary}

A review is given of 23 cases of coarctation of the aorta, 20 of which served in the recent war, and 3 in the 1914-18 war.

These men had been fit prior to enlistment and were of good physical development. They were able to withstand the severe stress of war service for long periods before symptoms occurred.

The most constant clinical signs of coarctation were a raised blood pressure in the arms associated with a diminished femoral pulse, evidence of a collateral circulation, a systolic murmur audible over the front and back of the chest, and abnormal pulsation at the root of the neck. The 
most constant radiological signs were erosion of the ribs and absence or smallness of the aortic knuckle.

Severe hypertension may persist for many years in these cases without causing heart failure and some may live a normal span of life. The later the symptoms appear the better the prognosis.

I wish to thank Dr. Prideaux, Director General of Medical Services of the Ministry of Pensions, for his permission to publish this paper.

\section{REFERENCES}

Abbot, M. E. (1928). Amer. Heart J., 3, 574. (1936). Atlas of Congenital Cardiac Disease, New York.

Blackford, L. M. (1928). Arch. intern. Med., 41, 702. Bramwell, C. (1947). Brit. Heart J., 9, 100.

Campbell, M., and Suzman, S. (1947). Ibid., 9, 185.

Dock, W. (1932). J. Amer. med. Ass., 99, 2024.
Eppinger, E. C., and Mittelfart, P. A. H. (1933). Amer. J. med. Sci., 185, 528.

Lewis, T. (1933). Heart, 16, 205.

Perlman, L. (1944). Amer. Heart J., 28, 24.

Railsback, O. C., and Dock,'W. (1929). Radiology, $12,58$.

Reifenstein, G. H., Levine, S. A., and Gross, R. E. (1947). Amer. Heart J., 33, 146.

Roesler, H. (1928). Wein. Arch. inn. Med., 15, 521. 